Meta

Journal des traducteurs

Translators' Journal

\title{
Translatology: Interrogative Musings on the Grid
}

\section{P. P. Giridhar}

Volume 50, numéro 4, décembre 2005

Pour une traductologie proactive - Actes

For a Proactive Translatology — Proceedings

Por una traductología proactiva - Actas

URI : https://id.erudit.org/iderudit/019841ar

DOI : https://doi.org/10.7202/019841ar

Aller au sommaire du numéro

\section{Éditeur(s)}

Les Presses de l'Université de Montréal

ISSN

0026-0452 (imprimé)

1492-1421 (numérique)

Découvrir la revue

Citer cet article

Giridhar, P. P. (2005). Translatology: Interrogative Musings on the Grid. Meta, 50(4). https://doi.org/10.7202/019841ar

\section{Résumé de l'article}

Cet article tente de rendre compte de ce qui se fait dans le domaine des études relatives à la traduction de nos jours. Il affirme que la théorie de la traduction n'a pas réussi à bien cerner sa problématique et elle se sent coupable de ce fait. Cette dernière a été incapable d'atteindre ses objectifs et n'a pu placer les choses dans une perspective rationnelle. L'article soutient que l'opposition putative entre le « tour linguistique " et le « tour culturel » est faite à tort en mettant en relief la dialectique entre la langue et la non-langue( Rajendra Singh (2005) parle d'un « re-tour ». La théorie de traduction est coupable de ne pas mettre en place une rigueur academique suffisante qui doit caractériser toutes les poursuites académiques. Cet article suggère une plus grande rigueur et moins d'hyperactivité dans les études portant sur la traduction. Le fait qu'il n'y ait pas encore de théorie de traduction est inacceptable. Cependant, je ne suis pas d'accord avec Peter Newmark affirmant qu'il ne peut pas y avoir de lois ou de theorie de la traduction. Cette position est trop extrême. Cela est egalement vrai pour la théorie littéraire. " Théorie » est un mot inadéquat pour exprimer ce qui correspond à une série de principes qui régissent le phénomène littéraire et qui les mettent en relief. Ce qui existe de cette rigueur d'approche dans le domaine des études de la traduction est insuffisant par rapport au domaine par exemple de la physique nucléaire. Mais une chose qui est libre et aisée dans un sens absolu ne peut pas être utile d'une manière significative. Une créativité libre ne peut pas aboutir au sens. Une force centrifuge sans contrainte et sans limite où tout s'accomode est en fait un exercice intellectuel creux vide de sens. Le virage culturel dans sa version forte effectue un changement radical dans la fonction de la traduction et rend la trace de la presence du traducteur trop visible. Au moins, ce tour culturel est inexactement rapporté et, dans un sens, ce que j'espère démontrer, exagérément rapporté. En essayant d'élucider l'interrogation pourquoi les choses sont telles qu'elles sont, cet article conclut en disant qu'il faut que les etudes théoriques de la traduction fassent un effort pour arriver à un discours valable sur les plans interlinguistique et interculturel, à un discours qui soit fondé,autorisé, activé et étayé par une grille bien établie, libre de culture mais soumise au changement rationnel. Cet article a donc pour objectif de corriger les choses, du moins les tenir en bride. Ce qui est dit à propos de traduction s'applique aussi à la literature. Cet article aura atteint son objectif si les interrogations sont soulevées. Les réponses pourraient tarder à venir.
Ce document est protégé par la loi sur le droit d'auteur. L’utilisation des services d’Érudit (y compris la reproduction) est assujettie à sa politique d'utilisation que vous pouvez consulter en ligne.

https://apropos.erudit.org/fr/usagers/politique-dutilisation/ 


\title{
Translatology: Interrogative Musings on the Grid
}

\author{
P. P. GIRIDHAR \\ Central Institute of Indian Languages, Mysore, India \\ sakalya_2000@yahoo.com
}

\begin{abstract}
RÉSUMÉ
Cet article tente de rendre compte de ce qui se fait dans le domaine des études relatives à la traduction de nos jours. Il affirme que la théorie de la traduction n'a pas réussi à bien cerner sa problématique et elle se sent coupable de ce fait. Cette dernière a été incapable d'atteindre ses objectifs et n'a pu placer les choses dans une perspective rationnelle. L'article soutient que l'opposition putative entre le «tour linguistique » et le « tour culturel » est faite à tort en mettant en relief la dialectique entre la langue et la non-langue( Rajendra Singh (2005) parle d'un « re-tour ». La théorie de traduction est coupable de ne pas mettre en place une rigueur academique suffisante qui doit caractériser toutes les poursuites académiques. Cet article suggère une plus grande rigueur et moins d'hyperactivité dans les études portant sur la traduction. Le fait qu'il n'y ait pas encore de théorie de traduction est inacceptable. Cependant, je ne suis pas d'accord avec Peter Newmark affirmant qu'il ne peut pas y avoir de lois ou de theorie de la traduction. Cette position est trop extrême. Cela est egalement vrai pour la théorie littéraire. "Théorie » est un mot inadéquat pour exprimer ce qui correspond à une série de principes qui régissent le phénomène littéraire et qui les mettent en relief. Ce qui existe de cette rigueur d'approche dans le domaine des études de la traduction est insuffisant par rapport au domaine par exemple de la physique nucléaire. Mais une chose qui est libre et aisée dans un sens absolu ne peut pas être utile d'une manière significative. Une créativité libre ne peut pas aboutir au sens. Une force centrifuge sans contrainte et sans limite où tout s'accomode est en fait un exercice intellectuel creux vide de sens. Le virage culturel dans sa version forte effectue un changement radical dans la fonction de la traduction et rend la trace de la presence du traducteur trop visible. Au moins, ce tour culturel est inexactement rapporté et, dans un sens, ce que j'espère démontrer, exagérément rapporté. En essayant d'élucider l'interrogation pourquoi les choses sont telles qu'elles sont, cet article conclut en disant qu'il faut que les etudes théoriques de la traduction fassent un effort pour arriver à un discours valable sur les plans interlinguistique et interculturel, à un discours qui soit fondé,autorisé, activé et étayé par une grille bien établie, libre de culture mais soumise au changement rationnel. Cet article a donc pour objectif de corriger les choses, du moins les tenir en bride. Ce qui est dit à propos de traduction s'applique aussi à la literature. Cet article aura atteint son objectif si les interrogations sont soulevées. Les réponses pourraient tarder à venir.
\end{abstract}

\begin{abstract}
This essay attempts some regurgitation of what has been happening in TS these days. It argues that Translatology has culpably failed to address issues and has instead moved around without quite getting things into a rational perspective. It argues that the putative opposition of the 'linguistic turn' and the 'cultural turn' in TS is misplaced, by spotlighting the language-nonlanguage dialectic. (Rajendra Singh (2005) argues for a 're-turn'). Translatology has culpably failed to work toward the rigour that characterizes, or should characterize, all academic disciplines. This piece is a plea for more rigour and less hyperactivity in TS. That there is as yet no theory of translation is unarguable. None is there to be sighted on the horizon. I don't agree with Peter Newmark on the other hand that there can be no laws or theory of translation. That is too strong a position to take it seems to me. (Equally obvious is the averral that there is no theory of literature. 'Theory' is too strong a word to use for whatever exists as a set of organizing or underpinning principles that govern the phenomenon of literature.) Whatever TS theory may be said to exist lacks muscle tone in a way in which Nuclear Physics, for example, does not. That Nuclear Physics is a physical or natural science and TS is Humanities is no argument. The point is that anything that is unconstrained in an absolute sense, in a transcendent sense cannot be piquant in any meaningful sense. Unbridled or barely bridled creativity cannot be meaning-making. Absolutely untrammeled centrifugality where
\end{abstract}


everything and anything 'goes' is in point of fact an intellectually vacuous exercise. The 'cultural turn' in its strong version effects a radical change in the ' enabling function' of translation and converts the 'traces' of the translator's presence into a massively visible one. At the least the 'cultural turn' is misstated and, in a sense, which I hope to make clear, overstated in the sense of throwing the floodgates open, which isn't a hallmark of an academic discipline. Attempting an elucidation of why things are the way they are in TS the note concludes that TS must strive toward a crosslinguistically and crossculturally valid discourse about translation, a discourse grounded in, sanctioned by, driven and underpinned by a well-founded, crossculturally valid but subject-torational-change grid. This piece is intended therefore as a corrector and some kind of a reiner. As indicated at places what is said about translation applies equally to literature. The piece would have served its purpose if the interrogatives get home. The answers could take a while to come by.

\section{MOTS-CLÉS/KEYWORDS}

grid, linguistic turn, cultural turn, nonlanguage, intellectual vacuousness, constraints

If one strays from the marriage-bed, there are two major positions one can take in a nonanarchic society:

1.(a) say that there is a behavioral grid, a social code that goes with the institution of marriage but confess that one is violating it clandestinely and culpably. (b) argue that that behavioral code is ill-founded and so one is free to do whatever one wants, in which case the straying is not culpable and need not therefore be clandestine. In which case it is in point of fact not 'straying' at all. 2. To aver that there was never such a grid of behavior constraining and binding one.

Position 2 does not tenably exist, it seems to me, except of course in an anarchic state of society, where 'everything' and 'anything' goes, which is not the kind of social habitat we are talking about. Underpinning every intellectual human endeavor there is such a grid, a mental matrix, which is defined in some rational way. This is very clear, even obvious, in the case of the exact sciences, the hard sciences, the formal sciences, the natural sciences. In the case of these sciences such a grid is very solidly and stablely defined. The uncertainty principle of Quantum Mechanics, I am afraid, does not counter this position, which is basically a position of rational rule-governedness. The nature of quanta of light energy is uncertain. The observer's eye changes them. How does this invalidate the essentially rule-governed nature of natural phenomena? This grid is of course subject to variation, revision and change, which is a function of the progress in that field. It is subject to chopping and changing in this sense. In fact an ingenious subsequent contribution can substantially alter the shape of the grid. But such a contribution is NOT an arbitrary or subjectively inspired flight of creativity or imagination but is propelled almost inexorably by principles of delightful rationality that brought the grid into being in the first place. Any contribution that is not founded on such principles of rational argumentation is promptly consigned to the dustbin by a critical but universal consensus. This is the beauty of these sciences. This is the grid that ensures the intellectual nonvacuousness of these enterprises. This is the grid that has resulted in such spectacular progress in each of these disciplines. There is an elegant and solid body of knowledge that evolves incrementally and accretively in these sciences through such rational contributions built on an existing understructure of knowledge.

There is no such grid for literature as of now, the hoary tradition right from Aristotle and Plato notwithstanding. One can write anything, in form and content, and be accepted, accoladed and serenaded in her own camp. All creativity, including literary and translational creativity, I submit, derives its validity from its resonance with a noncreative poppycockish part which is at a given point of time pretty well defined and is universally consensual, which itself, mind you, is subject to change. In no sphere of human activity, I submit, can it be true that whatever anyone says/does is ipso facto correct, valid or true. This is true everywhere, I guess, and is part of being human. Whatever an Einstein or a Gandhi or a Derrida said or did or whatever a Chomsky or a Mandela or a Bush says or does can not be ipso facto correct/valid. Whatever a person or a group of individuals or society believes in can not be ipso facto correct/valid. Whether it is valid or correct is decided by the grid, which is by definition impersonal and neutral ${ }^{1}$. TS can not be an exception to this. In other words whatever the translator does (as indeed the creative writer does) can not be 
ipso facto correct or valid. The translator's work, as the creative writer's, should be assessed for its value and place in the disciplinary cosmos with reference to a crossculturally valid explanatory grid. As it is, such a grid is far from being rigorous. For example, in Peter Newmark's opposition of 'communicative translation' to mean 'capturing the effect the original had on the source language readers' vs. 'semantic translation' to mean 'capturing the context of the (sentences of the) original text' is unfortunately imprecise because investing the words 'communicative' and 'semantic' with this kind of technical charge is at variance with, and does unacceptable violence to, their known and universally accepted meanings. The 'cultural turn' which is even otherwise unjustifiable because it both misshoots and overshoots the target, as I will try to argue, makes matters worse for TS. This is the burden of this piece.

There is surprisingly little reaction to the 'cultural turn' in the TS literature. One such rare reaction is Clifford (1997). Clifford (1997) shows how postcolonial discourse with its one-sided emphasis on a purely nonessentialist position runs the risk of reducing the complexity of the situation it intends to describe by reverting to a dichotomy which is highly questionable, that of tradition and renewal. "Isn't it time" asks he, "to sidestep the reverse binary position of a prescriptive antiessentialism? Struggles for integrity and power within and against globalizing systems need to deploy both tradition and modernity, authenticity and hybridity - in complex counterpoints." (Cliffords 1997:178)

Like literature, I submit, TS has no such grid either driving its progress, sanctioning what the translator does in terms of its resonant relationship with the noncreative part. One can manipulate the original text, even upstage it in the service of power and ideology and get away with it. One can do ANYTHING with the original. There is a joke doing the rounds in translation circles in Bangalore, and that is that translators who swear by fidelity to the original are said to be suffering from muula-vyaadi literally source-disease (='piles')! ...the study of translation, Bassnett (1999:11) avers, involves mapping the journeys texts undertake. The objection to this observation is that translated texts don't undertake journeys but translators steer these texts onto taking the roads they do take. In fact this is just the opposite of the trend in literature today. Imaginative literature, it is averred, should not be tendentious, should not be agenda-driven. The current in TS is the opposite. Translation could be, even should be, tendentious and agenda-driven. The more tendentious, the more politically driven a translation is, the more excited TS scholars are, it seems! ('prescriptive antiessentialism'!)Translations, one is told, are functions of the translator's socioeconomic background, her ideological propensities, her gender, her age, nationality, her ethnic identity and whatever it is that you can identify a translator by, her colour, her marital status, for example. Even nonliterary, scientific translations are not an exception to this, people say, a noticeably gleeful did-you-know-that-you-dunce glint in their eyes.)

The 'cultural turn', also called the 'postcolonial turn', has been around since the 1980's. This basically means translating the enveloping culture underlying the linguistic form, the web of signification, as Geertz had it, that man weaves around himself and in which he stays suspended. An explicit definition of this turn comes from its most ardent advocates viz. Andre Lefevere and Susan Bassnett (1990:8): "Neither the word, nor the text, but the culture becomes the operational unit of translation".

Taking this to be paradigmatic of the 'cultural turn', let us examine it to see what sense it makes. One could note to begin with that this privileges the world over the word, the culture over the text, which is just as well. However there is obviously something wrong with this characterisation. When we say 'translate this word', what we mean is 'put what this word means into the target language form which expresses it' or 'disembody the content in code A and reembody the same content in code B'. 'Translate this text' would mean 'put what this text means into a target language text which expresses it', or 'disembody the content of the text of code A and reembody the same in code B'. This meaning, which is the target of all translation, is the sociocultural world, the cultural cognition that all languages encode or give vent to. Is there anything other than culture which has to be translated, especially when, by their own admission, language is a distinctively cultural vehicle, a cultural phenomenon par excellence? What is meant by saying that culture becomes the unit of translation? How do we arrive at this culture which has to be translated except through the text which is an embodiment in language? The culture is embodied in language, in particular in the specificities of the language of the text. We already see how TS is moving away 
from groundedness to something very airy, not easy to catch and almost ineluctably ambivalent. This is what leads to what they call the 'larger' picture that 'linguistically oriented' translations don't allegedly capture, to 'translator subjectivities beyond reason' (Robinson (2001))'s expression) which are perhaps what lead to the delightfully open position of the translator being able to do anything with the original!

Before we take up a text to find out what this could mean, let's sort out this 'cultural stuff' with regard to words and turns of phrase. There is some clutter here as well, which needs to be cleared. A famous example of one such word would be the Sanskrit word dharma, which is putatively untranslatable because it putatively has an awe-evokingly heavy cultural weight. I don't agree, to begin with, with the averment of the untranslatability of this word. At the least its untranslatability is grossly and mindlessly exaggerated. Bhalla (2003:15) asserts such words as dharma, nirvana and catharsis, although "they do seem to be difficult to translate..., nevertheless do not bring us to the abyss of incomprehension." And that "they only call for a greater 'hermeneutic alertness' on the part of the translator". My submission here is that, in its various collocations, the word dharma is quite delimitable and is delimited in its meaning. In Kannada, a South Dravidian language, for example, the compound word dharma patni 'dharma-wife' for example, means simply, and no more and no less than, 'legally wedded wife'. It does not mean anything else. In dharma chatra it has the meaning of 'charitable', the compound collocation meaning 'a free charitable public dwelling place'. In application forms to be filled in by candidates the word dharma means 'religion' and nothing else. It need hardly be said that there is no bivariateness of meaning - linguistic and cultural - to the word. A turn of phrase like kick the bucket also has only one nonambivalent meaning viz. its noncompositional meaning of 'to die' unless the situation dictates its compositional meaning of someone moving his feet to strike the bucket. There is no such thing here either as an opposition of linguistic and cultural meaning. To say that there is a linguistic meaning either of words or texts leading to translation of language leading to the linguistic turn which one can oppose to what could be called cultural meaning leading to translation of culture leading to the cultural turn somehow lacks perspective. In the sound-sense contract that human language is, is the 'sense' susceptible of such a dichotomy? This is intended as a rhetorical question! If the meaning of nirvana and catharsis are externalisable in any language then one could arrive at a reasonably good translation in any language. Only, resorting as it would to 'compensatory glossing' or what is called 'extratextual writing', and 'paratextual writing' the translation would not in all probability be holophrastic which fact would dent the architecture of the text in which these putatively untranslatable words occur, and thereby its communicative impact. I of course agree that such many-to-one correspondences across languages seriously affect the expressive (and affective) dynamics of the text. The now famous example is that of the tripartite second personal pronoun in Hindi/Urdu tuu ('you (singular and possibly intimate')), tum ('you singular and respectful or plural') and aap ('you (extrahonorific when singular, otherwise plural)') which corresponds to the monopartite you in English so that the Urdu poem-part

aap ban gayii tum

tum ban gayii tuu

has to be per force translated into English as

You became you

and you became you!

Which is obviously not as expressive as the Urdu original. There is no doubt about the untranslatability of some linguisticisations of conceptual space. There is absolute translatability, absolute untranslatability and relative translatability. In Giridhar (1991) I argued that some literary meanings are irretrievably lost in translation simply because languages are structured the way they $\operatorname{are}^{2}$. The point germane to this essay would be that this untranslatability has nothing to do with the linguistic meaning /cultural meaning opposition that is being foisted on us. Languages are, simply, ways of looking at the universe. It is difficult to see within a linguistic code a cultural way and a linguistic (= noncultural) way of looking at the universe! 
Are the proponents of the linguistic turn/cultural turn dichotomy making a distinction within the realm of nonlinguistic thought that language is there to express between what could be called 'linguistic translation' and what is usually called 'cultural translation', which in turn are what make for the linguistic and cultural turns in TS ? If this is what they mean, then something like the following is happening:

nonlinguistic thought lending itself to linguistic translation in code B

linguistic form in code $\mathrm{A}$ (word, sentence or discourse)

nonlinguistic thought lending itself to cultural translation in code B

'Is nonlinguistic thought susceptible of such a dichotomy?' is the question.

Another sense, broached earlier, in which the cultural turn/linguistic turn opposition is used is that you take culture as the unit of translation and translate a text. Has anybody shown that a translation taking culture as the unit of translation and a parallel translation taking whatever the other unit is as the unit of translation are distinctly and axiologically different things? In particular, are they different from what are called 'literal' and 'free' translations? How? They are presumably different from what used to be called 'sense-for-sense' translations as opposed to 'word-for-word' translations because they go beyond the sense and do something different? Such translations are culturally colored, culturally relevant free translations. The position expressed in statements like 'One does not translate languages but cultures' or 'In translation we transfer cultures, not languages' (House 2002:92) is no big deal and is hardly a new discovery precisely because that is what ALL language is about. This is not special to translation. Nonlinguistic thought or meaning is what language cognises and codifies, and that is what language is exactly there for. Nonlinguistic thought or meaning is the raison d'être of language so that a statement like 'Since in translation meaning is of particular importance it follows that translation cannot be fully understood outside a cultural frame of reference' (House 2002: ibid) makes no special sense. Nor do statements like translators are "agents of culture rather than transmitters of words" (Barsky 1996:46). I mean these don't represent advances in our knowledge of human language ${ }^{3}$ and hence, I submit, contrary to what people think, don't represent any advance in our awareness of translation. This amounts to saying that the 'cultural turn' isn't saying or said anything new (er than the literal/free translation). There are translation teaching softwares that evaluate a translation on a literal/free cline, and it is hard to see how this would be crucially different from a linguistic/cultural meaning cline or a text-as-unit and culture-as-unit cline.

What would be the English translation in the 'linguistic turn' of the following paragraph of the celebrated Kannada literary artefact called KUSUMA BALE (1984), and what is its translation in the 'cultural turn', parallel translations that stand opposed to each other?

kuusu huTToodaku muurjinaka muncitavaagi saikalluu aa saikal kyaariyarnall sakkara tumbida byaagalli iLididda kiTTayyanigaaga gaNDguusaada sambhramavu tuLukaaDta tuba aa saikala tiiDta tiiDta ada thaLa thaLva maaDta maaDta adu thaLaguTTaada myaalza inneenuu maaDaluu innentuu maadaluu kayya bandara kaalu baraduu kaalu banadara kayya baaradu. Antaagittalla aaga kiTTayyanu tolamyaakka tandeerisi iTtiddanatha aa tumbida sakkara iLusidavanu maadutalidda dadagubadagu daddugaLa arthavu 
naDudu bandu kepmii kivunga pisu guTtiti. Aa oNagida gaNTalu, angaLu, naaluga, tuTiga jala barsakaNDu kempiyu, tanna munda kuusaagi kuutiroo tanna avvaga “avai...aa muudeevi byaagin tumba iroo sakkaraniga ondaraLnuи buDde hancbuTT battada. Ondu bogasanaaru ettiTaga." andaLu. I maatu tuurammaga bacciccara uNTu maadi "nii teppaga malikammi” anadaLu.

\title{
An English translation follows:
}

\begin{abstract}
Kittayya, who had on his cycle-carrier, brought home a bag brimming with sugar three days before the child was born, was now brimming with excited enthusiasm, the excitement of having had a baby boy. His excitement showing in his body language, he rubbed his cycle vigorously, and as the cycle shone, his limbs went numb, unable to do anything. After a while however reaching for the bag of sugar which he had placed on the rafter, he held it, hugged it before putting it down on the floor. The meaning of the noises that he was making as he got the sugar bag down traveled to Kempi and whispered something into her ears. Wetting her throat, palate, tongue and lips with her saliva, Kempi said to her mother sitting, child-like, by her: "This fellow will take away the whole lot for distribution to people. He won't let even a single grain remain. You go keep aside atleast a palmful!" Jolted awake, Juugamma quipped, "you sleep without a word, girl!"
\end{abstract}

Now, it may be, and in fact is, entirely possible to do multiple translations of this chunk as indeed of the whole work of art. But is it possible to do a translation of this in which one takes the text as a unit of translation and oppose it to culture as an operational unit of translation? I don't think it is. This is because there is no such dichotomy in the world of nonlinguistic thought. What however is possible is taking the sense of the original as a point of departure and doing a rewriting in the target language to suit the requirements of the target culture, to achieve 'differential plurality', treating translation as a culturally relevant mediation between two ethoses, which is a distinctly different enterprise, and which is part of what postcolonialism aims at. Barsky (1996) is a seminal paper, I think, in understanding the intellectual content of the postcolonial turn in translation. Barsky points out that in Convention Refugee Hearings, or for that matter in any litigation (my addition), rather than attempting an accurate and fluent translation the interpreter should seek to improve the chances of the claimants getting a fair hearing. In which case he may be required to do more than a faithful and fluent translation. He may be called on to recast the utterances of the claimant, coming as they might from different narrative traditions, "into an acceptable format..., minimising the damage by mediating culture-specific attitudes" (Barsky 1996:53f.). He might be impelled to tell an appropriate and compelling story or an anecdote by using examples acceptable to the target culture. This is one example where translation may be said to aim at nonclose linguistic equivalence as opposed to 'close linguistic equivalence' (Bassnett 1980). There is a rational or ethical agenda that drives the interpreting/ translation which subordinates the target culture to the source culture in the interests of the authenticity of the source original. Fair enough. A strong or extreme version of this is what is impugned in this paper because that is what militates against the requirements of a rigorous academic discipline. This kind of interlingual re-creation is part of what is called 'creating paths' to the TL. This process of path-formation, I submit, does not invoke a linguistic/cultural (turn) distinction that could be argued to be different from a literal/free opposition. Whatever the translator does has to be through language. It has to be linguistic in that sense. But as I hope to have shown, the issue is more than a terminological quibble involving the word 'linguistic'. The issue has to do with our understanding of what language is about. In the light of the fact that language is there to express nonlanguage, and nonlanguage makes no valid distinction between what can be called 'linguistic' and 'cultural' meanings to justify the 'linguistic' and 'cultural turns' in TS, an opposition between linguistic and cultural translation as is implicit in the linguistic and cultural turns seems hard to justify. It seems hard to justify a translation with culture as the operative unit of translation, which is different from the sense-for-sense translation, or, better, 'free' as opposed to 'literal' translation. There is in the literature some hint that sensefor-sense translation refers to the translation of individual words or phrase 'according to their grammatical form and meaning in the text', not 'according to the wider contextual meaning'. (Cf. Lambert 1991:7) This would presumably mean a context that extends outside the text. Does this make good sense? All literature is socioculturally embedded, which is to say all individual literary artefacts inhabit space part of which or, indeed a lot of which, obviously exists outside the text, in 
the sociocultural world which made the text possible.. What are we saying when we say 'cultural translation' would mean 'translating with contexts extending beyond the text in mind'?

The confusion could also be because of the mistaken assumption that one could privilege the word over the world. Privileging the word over the world which means focusing on form to the exclusion of content, I submit, does not happen anywhere in language use except in exceptional instances among others like language pathology, language pedagogy and pediatric language games. In its genesis as in its continued use, human language is there to focus on nonlinguistic worlds, to express nonlinguistic thought. Language is a delightfully effective and excitingly efficient cognitive vehicle and tool in man's journey through life on this planet. Focussing on the vehicle/tool for its own sake makes no sense! I submit that this privileging of form over content does not happen despite protestations to the contrary even in creative literature. What makes imaginative literature worth serious and extended pursuit is not, I submit, the way language is used (See Giridhar 1976, 1978 and 2005), but the fact that it makes interesting, sensible and powerful statements about nonlinguistic worlds, kicking open the doors of our nonlinguistic consciousness, teasing it into new awarenesses, shocking it, cajoling it, transporting it into totally new and exciting horizons, rearranging the intentionally ordered information that human consciousness is, thus heightening and enhancing, generally raising the bar of, our mental existence, and disclosing new avenues of thought and so on. A heightened use of language in poetry, which demands a heightened sensitivity to language on the part of the reader, is a result of letting your meaning choose the linguistic expression. An ordinary speaker of a language finds herself under no pressure to use language the way a poet does. It is in other words not the case, or it is untenably strong to say, that the ordinary speaker is intrinsically unable to make what is called the 'poetic' use of language.

All human creativity especially that which gives rise to constructs of the human consciousness is some kind of 'imagined rationality', it seems to me. It can not be unconstrained no-holds-barred flights of imagination. A clear-as-daylight rationality governing literature, for example, is the essentialist idea that part of being human is to be responsive to and protective of life and civilization. Engineers of the soul that writers are supposed to be, this burden has to be shouldered by them. There is grievous and culpable lapse of rationality in the praxis both of literature and TS about this. 'Everything' and 'anything' goes. I asked a distinguished TS scholar and TS teacher for decades what she (This is referentially she, not the concessive feminism-driven evener she) thought of the idea argued persuasively by Bhalla (2003), for example, that the translator can not for example communalise a noncommunal literary piece. Her response is typical of the state of affairs in TS. Her response was that she does not relate to such constraints, and she was for no-holds-barred creativity. This I thought was strange, even funny ('zany' is the word), being as it is an academically irresponsible and intellectually unaccountable stance. It is clear that a translator has no business to carnalise a noncarnal piece or communalise a noncommunal piece, or generally demean an original. I agree holus bolus on the other hand with the sociocultural embeddedness of translation as a phenomenon, and as practice. (The sociocultural embeddedness of literature and translation on the one hand and of language on the other are not on the same footing though.) There is something called a 'translating consciousness' which is not an automated machine and that the translator is not a photographer who duplicates the original in another linguistic code. Her job is not just to transfer 'determinate semantic cargo from one phonetic vehicle to another'. The redoubtable Theo Hermans (2002) puts this beautifully which is why what he says bears reproduction here:

Translation is of interest as a cultural phenomenon precisely because of its lack of neutrality or innocence, because of its density, its specific weight and added value. If it were a merely mechanical exercise, it would be as interesting as a photocopier. It is more interesting than a photocopier in that it presents us with a privileged index of cultural self-preference, or if you prefer, self-definition. The practice of translation comprises the selection and importation of cultural goods from outside a given circuit and their transformation into terms which the receiving community can understand, if only in linguistic terms, and which it thus recognizes, to some extent atleast, as its own. And because each translation offers its own, overdetermined, distinct construction of the otherness of the imported text, we can learn a great deal from these cultural constructions - and from the construction of self which 
accompanies them. The paradigms and templates which a culture uses to build images of the foreign offer privileged insight into self-definition.

I also agree, and this is a corollary of the above, that any translation which, as Benjamin pointed out, does no more than perform the function of transmitting information is a bad translation. Again as Benjamin (1970) pointed out, translations could breathe new life into the original text to ensure its survival and continuity, which notion warranted the term 'donor' text rather than 'source' text. This however does not mean that the translator can do anything with the original, does it? The value-addition that the translator does has to be constrained in terms of academically rationally defined filters. And these academic filters and constraints issue from the grid. It was Chomsky who repeatedly and rightly, talked of constraints in grammar and constraints in language. All creativity has to be and is constrained in ways that can be identified sooner than later. It stands to reason that there has to be something in TS which directs research in TS, a welldefined, well-founded cerebral matrix, a mental representation, a 'grid'; as I have called, which sanctions things, constrains what can happen in the field, which itself is subject to well-founded change, as in the case of the natural sciences.

One, or atleast I, would be perfectly happy if people concede that translation, as is indeed literature, is a highly subjective phenomenon, and hence is not subject to rational analysis, unlike let's say, Nuclear Physics or Paediatric Audiology or Molecular Biology. There is no science or objective study of translation but only a phenomenology of translation, no science or objective inquiry of literature but only a phenomenology of literature. I even fell back satisfied when somebody answered a long-standing objection of mine to literature which was how it is that literature as a body of knowledge can filter nonsense like, let's say, a piece which endorses fascism, or caste as a social category in India, or head-hunting as a cultural practice in some communities, or to put it in more general terms, a literary piece which makes categories that exist in human societies but which are outside human ontology look positively ineluctable. Such pieces of literature surely have no justifiable existence. ${ }^{4}$ As I said such works culpably continue to be serenaded. I was told that time and people would see such stuff consigned to the dustbin of history. This I thought on further reflection was not satisfying because disciplines like Nuclear Physics do not depend on time and people to consign nonsense to the dustbin. This is done by some delightful consensus by the rationally driven grid that underpins the discipline. How on earth can an academic discipline worth its salt depend on people and time to screen out nonsense? To this somebody said literature was not a 'discipline' in that sense, which makes a lot of sense. That is it. Literature is not a discipline in an intellectually credible sense, which is why it does not have an underpinning grid of the kind that disciplines like Nuclear Physics have, which is why the credibility of new entrants to the field is not evaluated with resonant reference to the noncreative part which all creativity entails and which was broached earlier. This could very well be. However this can not be the case with something like translation simply because translation is an operation on an object that already exists, an object with its own internal rhetoric and ontological dignity that is there for all to see.

The scenario however is not as hopeless as it may be made out to be. One quite sees that there is an attempt howsoever feeble on the part of the practitioners in the field to provide a generalised theorised underpinning to the whole enterprise. After all man is a pattern-seeking, order-seeking animal. Thus 'fidelity' to the original as a measure of translatorial ontology was one such theoretically laden construct, which is being increasingly replaced by 'relevance' to the target culture, which makes a lot of good sense. Bound up with fidelity was this literal/free continuum. 'Abusive fidelity' (Philip Lewis's term) was another. 'Foreignising' as opposed to 'domesticating' is another. 'Covert' translation as opposed to 'overt' translation is a third. The notion of 'translation universals' is a fourth. Another heartening development has been the coming forth of 'relevance-theoretic' treatments of translation. (Gutt 1991 (second edition 2000))...But these are fledgling attempts. The field is in desperate need of more rigour. The field should address questions that legitimately belong in its domain of enquiry like why it is that the best possible, the best conceivable translation in language B of a work in language A leaves the bilingual unsatisfied. This despite the fact that humans all over are biologically and cognitively prewired identically. The answer surely is in the language, in the ways languages encode nonlinguistic content. Questions like why intralinguistic translation is prima facie unable to carry forth the flavour and timbre of a 
dialect to which a possible answer could be that there is something code-dependent about linguistic meaning, the idea that the meaning that escapes the code is no longer it, and so on. There are of course legitimate nonlinguistic questions of how translation engages with issues like alterity, subjectivity, selfhood - individual and communal, (the construction of) identity, hybridity, the dialectic resonance between cultures, nation-building, human ontology, human rights, human consciousness, epistemology, the Other, civilisational habitat and space, the role of translation in literary-movement formation, literary canon-formation, translation as an agency of cultural dialogue, and translation as a catalyst of social change, translation as reflective of the nature of sociocultural space at a given time, translation as indicative of sociocultural processes, and so on and so forth. Instead of addressing questions like these one would find stories and stories in place of any objective (=rational) analyses of the piece of translation. One finds the TS literature flooded with treatises and disquisitions which are either very exuberant but airy nothings or belong more to literature, aesthetics, sociology, culture studies rather than to Translation Studies proper. It is not enough to say that TS draws upon other disciplines for its subject matter. It is absolutely essential that TS has its questions to address, questions which may be argued to belong in its legitimate domain of inquiry to answer which it connects with or appeals to other disciplines. In case the questions and issues themselves are integral both to translation as a phenomenon and to other disciplines, then there arise doubts as to the legitimacy of TS as a discipline in itself. Then there is a case for hyphenated disciplines which have translation as a part of them, like Translation-Literary Studies, or Translation-Cultural Studies, Translation-Aesthetic Studies and so on. Or is it something like the omnibus Environmental science which proposes to advance our understanding of our environment through inputs from ecology, the geosciences, hydrology, the biosciences, the vegetation science, atmospheric sciences and so on?

The grid that I have talked about and the related fact of the dialectically resonant relation between creativity and the noncreative part of human cerebration should in tandem lead to what one would like TS to achieve in the end. That end toward which TS should (as indeed should Literature) relentlessly strive is the goal of cross-culturally and cross-linguistically valid ways of talking about the being of a (translated) work of art .Therein lies the essential academic validity of the translated piece. Therein lies its place in the cerebral cosmos of the discipline. Describing a translated piece however ingeniously and in however detailed a manner in terms which are rigorous but are confined locally to the piece achieves almost nothing, unless of course one delights in talking about the individual piece as an isolate and not situate it in a framework of reference which is populated by other pieces of translation, which activity some may find good enough but is clearly less interesting than the activity of defining its situatedness in an illuminating framework which is informed by the kind of things I have been talking about. In Linguistics for example we say a language should be able to be described in its own terms but at the same time in terms that range beyond the language being described. This is somewhat of a paradox. But that is why and how Linguistics as an academically viable and cerebrally credible discipline gets born. That is why and how all academic disciplines get born and get their intellectual credibility. If there is to be such a discipline of TS this must happen viz. we need to have terms in what could be called an underpinning grid, terms which range beyond the description and evaluation of individual translated pieces. This 'ranging beyond' is what leads to a generalized matrix and an explanatory framework of an academic discipline. The 'cultural turn' in vogue now which is a suspect development in TS, as I tried to argue in this paper, and indeed as Rajendra Singh (2005) has argued so persuasively, hardly leads one to a platform fraught with the positive possibilities of grounding the discipline in an inexorably solid theoretical grid. In fact it takes TS in the opposite direction because it is itself eminently unjustifiable in terms of any rationale. We need to worry about the way a 'free' ('infidel'?) translation aiming at target-cultural relevance and self-definition meshes with or fits into the idea set out in this paper of crossculturally valid ways of talking about translation. There are crossculturally valid ways of talking about music, sculpture, architecture and painting, which are all examples of 'imagined rationality' and are constructs of the human consciousness. So are literature and literary translation and there is no reason why there could not be crossculturally valid and rigorously discipline-enriching discourse about them ${ }^{5}$. 


\section{NOTES}

1. This is at variance with what Clifford Geertz (1973:49) thinks of what culture does to man He says that man has no nature independent of the particular culture he finds himself in. I think this is too strong a position to take. It does not reckon with (wo)man's great creative urge, with her delightfully unique ability to think wrenching herself free from the known, and from received wisdom. If what Geertz says is strictly true, how do we explain the fact of the path of man's progress paved relentlessly by his intransigent originality, innovative initiative and originalising creative spunk? I am intrigued by such pronouncements which people are still fond of making.

2. Phonologically contrived feedback to meaning is untranslatable. Look at the following English sentence group whose expressive dynamics goes untranslated in any other language:

My brain has two parts: The left and the right. In the right part there is nothing right and in the left part there is nothing left.

The smutty joke that 'children enjoy their childhood and adults their adultery' is a joke because of the speaker's confusion between adultery and adulthood. This would be untranslatable in other languages because there is no formally resonant relationship between these two nouns in those languages.

3. Academic heavyweights, otherwise distinguished, have said things about language which are wide off the mark. Derrida for example says linguistic signs have no meaning that is final or transcendent. This is no big deal. We knew this for centuries. Built around a relatively stable denotative core the meanings of words have an open-ended multiplex potential. The contours of a content word -- those of its grammar and of its lexical semantics -- are never finally drawn. Look at the following for example where contrary to expectations a proper noun turns into a verb:

1. Babita Bobbitted Bobby (=Babita depenised Bobby, Bobbitt being the name of a person)

2. IT has been Bangalored (Bangalore is the name of a place)

The most recent examples I saw of zero derivation are the words guilt, weapon and baby being used as verbs. The deferment of meaning that Derrida has talked about makes no sense either in the daily business of linguistic communication. All linguistic communication requires that there be a synchronically solid and stable system in terms of which there is communication. An ever changing and unstable code that postpones meaning of the kind that Derrida and his followers think possible leads to no successful communication. The fact that there is in the norm successful communication through language day after day after day after day, week after week after week, month after month after month, year after year after year, across the cosmos of every linguistic code is proof that there is no conceivable postponement of meaning and Derrida must therefore be wrong. The beauty of language is that it is at the same time a Procrustean bed and a code subject to lived experience, essentialist and free (or whatever is the antonym of 'essentialist'), centripetal and centrifugal, constitutive (=deterministic in the sense of 'creating thought') and representational (=reflective of thought) at the same time of reality.

4. I am sure there are examples of such literature everywhere in the world. A conspicuous example in Kannada literature is the novel entitled DAATU translated into English as Crossing Over (2003), which positively endorses caste as it is understood in India. (All powerful artistic creations radiate the exhilarating light of a universal oneness which our equally exhilarating and interestingly distinctive differences mask, which must be the reason why the best in every literature, the sublimest in every literature appeals to everyone irrespective of cultural differences. Empathetic appreciation entails a shared ground. I have warmed to, and indeed everyone warms to, the best of Tolstoy, the best of Dostovesky, the best of Gorky, the best of African, Commonwealth and Latin American writers almost at first reading.) Even a much hyped, much discussed and much translated novel like U R Ananthamurthy's Kannada novel SAMSKARA, I am afraid, falls into a subcategory of the same category although it has other positive qualities to recommend and redeem it. I agree with Suchetana Swarup (2003:410) that the writer of SAMSKARA concentrates on, hammers on, and wants the reader not to miss (what in the perception of the rabble is) the allegedly and ineluctably inherent superiority of the caste of Brahmins. How can writers, who are themselves die-hard caste- (or colour- or religion-...) supremacists, be engineers of the human soul that they are supposed to be? Such things should amuse any rational being. In the name of depicting social reality things are portrayed as if they are ineluctably final. (Some) social realities when they filter through a creative literary consciousness emerge, or need to emerge, with an undertone of disapproval unlike when they pass through an anthropologist's or a sociologist's consciousness. This is an essential difference between social sciences like Anthropology and Sociology 
and imaginary-world creating imaginative sciences like creative literature. This is an integral part of the imaginatively decisional act of ethical responsibility that serious creative literature (and serious literary translation) is. Our writers need to realise this. I was taken aback to learn the Kannada novel in question ('Crossing Over') was awarded the Central Sahitya Akademi (Central Academy of Letters, Delhi) prize, social recognition for a novel which has no business to be called 'creative literature'. This kind of recognition is a great comment on the quality of (the evaluation of) some of our literature as also on the people who dish out awards! More importantly, it fills with empirical content my charge of a lack of a constraining grid in literature, of the intellectual indigence, the cerebral vacuity and invalidity of a lot of stuff we call 'imaginative literature'.

5. Luminous and limpid lucidity may not be one of the virtues of this exposition of musings. However I am sure it throws up some thoughts for the TS community to mull, to rein in Translatologists who have gotten on their 'cultural turn' horses and are riding madly off. Thanks are due to Ms Susan Daniel of Ooty and Nilanjan Chakravorty, Reader in French, Dept of English and Modern European languages, Santiniketan, India for some piquant feedback.

\section{RÉFÉRENCES}

BARSKY, R. E. (1996): “The Interpreter as Intercultural Agent in Convention Refugee Hearings”, in The Translator 2-1.

Bassnett, S. and Trivedi, H. (eds) (1999): Postcolonial Translation: Theory and Practice, London and New York, Pinter.

BASSNETT, S. (1980/91): Translation Studies, London/New York, Routledge.

Benjamin, W. (1970): “The Task of the Translator", in Illuminations edited by Hannah Arendt, London, Jonathan Cape.

Bhalla, A. (2003): The Place of Translation in a Literary Habitat and Other Lectures, Mysore, Central Institute of Indian Languages.

Clifford, J. (1997): Routes, Travel and Translation in the Late Twentieth Century, London.

GEERTZ C. (1973): The interpretation of Culture, New York, Basic Books.

GIRIDHAR, P.P. (1976): “The Language of Literature: An Articulation of Its Distance from Everyday Speech", in International Journal of Applied Linguistics 2-1, New Delhi: Bahri Publications.

GIRIDHAR, P.P. (1978): "Poetic Licence: A Linguist's Eye view” in Linguistics in Literature 3-1.

GIRIDHAR P.P. (1991): "Structural Equivalence and Literary Translation: A Note”, in Language and Style 24-4.

GIRIDHAR P.P. (2005): "Language in Literature: Clearing the Ground”, in BHASKAR, R. B. (ed), El Dorado: An

Anthology on World Literature, New Delhi, AuthorsPress.

GuTT, E.(1991, $2^{\text {nd }}$ edition 2000): Translation and Relevance: Cognition and Context, Oxford/Manchester, Blackwell/St Jerome.

HERmAns, T. (2002): "Paradigms and Aporias in Translation and Translation Studies", in RICCARDI, A. (ed), Translation Studies: Perspectives in an Emerging Discipline, Cambridge, Cambridge University Press. House J. (2002): "Universality Vs Culture-Specificity in Translation”, in RICCARDI, A. (ed): Translation Studies: Perspectives in an Emerging Discipline, Cambridge, Cambridge University Press.

LAMBERT, J.R. (1991): "Shifts, Oppositions and Goals in Translation Studies: Towards a Genealogy of Concepts", in Leuven-Zwart, K. Van, and NaAijkens T. (eds): Translation Studies: State of the Art, Amsterdam: Rodopi. LefeVer, A., BAssnett, S. (eds) (1990): Translation, History, Culture, New York, Pinter.

RAMAKRISHNA, S. (2000): "Cultural Transmission through Translation: An Indian Perspective”, in SIMON, S. AND St PIERRE, P. (eds): Changing the Terms: Translating in the Postcolonial Era, Hyderabad, Orient Longman.

Robinson, D. (2001): Who Translates: Translator Subjectivities Beyond Reason, New York, State University of New York.

Singh, R. (2005): "Unsafe at any Speed: Unfinished Reflections on the Cultural Turn”, in KAR, P. C. and ST PIERRE, P. (eds): Translation: Reflections, Refractions and Transformations, New Delhi, Pencraft International. SwARUP S. (2003): That East This West, Hampi, Kannada University. 